\section{Europe and space}

AT last, a French phoenix has arisen from the ashes of the European summit at Athens last December. In Athens, President François Mitterrand of France apparently put paid to all hopes of negotiation with Britain over the future of the European Community. In The Hague last week, he explained his action: not directly, but by presenting a technological vision of a new Europe, in which the old conflicts would be something of a past age.

One element of this future would be a European space station, as a military observation post in the first place, but one that could also carry laser and other star wars weaponry for the defence of Europe.

Meanwhile, M. Mitterrand proposed only partial solutions to Europe's overriding political problem (the European budget), solutions which are unlikely to find favour with the crusading British Prime Minister, Mrs Margaret Thatcher.

Surprisingly, one of M. Mitterrand's most favoured ministers, M. Laurent Fabius (industry and research) seemed last week to have been caught a little un-

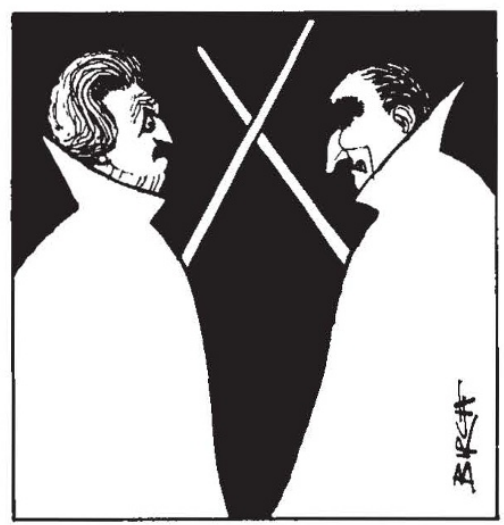

prepared by his president's commitment to a space station. Speaking at a meeting of European Parliament socialists in Toulouse, in south-west France, Fabius described the station as having commercial, scientific and strategic purposes with, it was implied, the "strategic" element firmly relegated to third place. The French space agency CNES had been studying the possibility of such a station for a few months, said an aide to M. Fabius, although the CNES director-general had earlier denied its.

Certainly, President Mitterrand has been taking an increasingly independent approach to European policy lately, so much so that French officials have occasionally been seen to be announcing conflicting policies. This apparent chaos, however, is probably the consequence of Mitterrand's commitment to a vision which becomes more dazzling — and perhaps more blinding - the worse becomes France's international and internal position. (Internally, Mitterrand is facing rioting in factories against his restructuring policies, and a probable rout at the European Parliament polls in the summer.)

Putting it boldly, the Mitterrand vision is this: the European Community is out of date - and so are Europe's defence arrangements with the United States. So why not try for something completely new?

The European Community, for example, is based on post-war treaties which saw iron, steel, coal and nuclear as the key economic technologies. Now the key technologies are electronics, informatics, aerospace and biotechnology. The Community must be based on these, says $\mathbf{M}$. Mitterrand, echoed by Fabius at Toulouse.

Equally, M. Mitterrand is disturbed by President Reagan's attitude to Europe, both technological and military, and with France outside the North Atlantic

Treaty Organization - he feels freer than most in Europe to propose something approaching an independent nuclear defence: hence the European space station.

Here, however, M. Mitterrand mixes military and industrial motives. While CNES has not admitted to a military space station study, it has since 1981 been studying a non-military one (dubbed Solaris), along with a recoverable low-orbit injector (Hermes) looking much like the space shuttle. Clearly, the object was to give Europe the possibility of recovery, repair, refuelling, construction and other options in space that the shuttle gives the United States but that Ariane has not given Europe (Ariane 5- already on the drawing board - could launch a future Hermes).

In M. Mitterrand's mind at The Hague, these essentially commercial questions of Europe's industrial place in space in the 1990 s were being mixed with other issues, but his overall dream was clearly of a brave new European Community based on brave new ideas.

Unfortunately, neither Mitterrand nor Fabius last week had much to say about mundane things such as the price of milk and the beef mountain, which may cause the French vision to become a mirage.

Robert Walgate

\title{
UN biotechnology
}

\section{Let a hundred labs bloom}

\section{New Delhi}

THE contentious issue of the location of the International Centre for Genetic Engineering and Biotechnology for developing countries, sponsored by the United $\mathrm{Na}$ tions Industrial Development Organization (UNIDO), seems to have been resolved. Although the original intention was to set up the institute in a developing country, the preparatory committee for the centre has now recommended that it is split into two components to be established in New Delhi, India, and Trieste, Italy.

The committee, meeting in Vienna at the end of January, suggested that the New Delhi component should concentrate on research in agriculture and human and animal health and that the Trieste laboratory should emphasize industrial microbiology and energy research. The offers from the two countries have been found to be most attractive.

A high-level meeting of the national representatives on 3 April will in all probability approve this decision, reached by the preparatory committee of 27 member countries. The committee was set up after the abortive Madrid meeting in September last year failed to decide on a location, following which more than one centre seemed a necessary compromise.

The decision reflects a major victory for India in the teeth of opposition from the UNIDO scientific committee which had favoured siting the centre in Belgium, Thailand or Italy. The committee said that these countries had sufficient merits to offer good prospects for the foundation of the international centre. India, like Cuba and Pakistan, had been ruled out on the grounds that its background in basic science is insufficient and that it would be difficult to attract good scientists.

This argument has now been rejected. What ultimately clinched the issue in favour of India was the specific outline of the offer involving some US $\$ 19$ million. The offer includes land, buildings and laboratories; technical and auxiliary staff; permanent equipment and $\$ 5$ million to cover recurring costs for running the centre for five years.

The government has promised that the New Delhi centre will have "high standards of scientific and laboratory facilities dedicated to solving problems relevant to developing countries in a highly focused and multidisciplinary approach". It will also provide training to scientific and technical personnel from developing countries.

The preparatory committee also tries not to displease the other nations that had also staked their claim to host the international centre. They can set up their own units affiliated with the New Delhi and Trieste centres and funds for them will also be provided through international sources. These affiliated units can be converted into centres by the board of governors of the new centre following a review after three years of operation by the New Delhi and Trieste Laboratories.

Sunil Saraf 